and other authors, were shown to agree with these later Tertiary andesites, both in their mineralogical constitution and in the peculiar phases which they present to us. The latest Tertiary ejections were shown in 1874 to bear the same relations to the five grand volcanoes of the Western Isles which the chains of "puys" in Auvergne do to the great central volcanoes of that district; and this conclusion is strikingly confirmed by petrographical studies of which the results were given in the present memoir.

\title{
OORZESPONDEITCE.
}

\section{AGE OF THE VOLCANIC SERIES IN SHROPSHIRE.}

SIr,-In reference to the debate on a paper "Un the Pebidian Yoredale Series of St. Davids," read by Prof. C. Lloyd Morgan before the Geological Society on the 8th inst., Prof. Blake is reported to have said that recent work in Shropshire "had shown that there was a volcanic series more satisfactorily classed with the Cambrian than with the underlying series." Though I have some familiarity with the older rocks of Shropshire, I am unable to call to memory any volcanic series that can by any reasonable stretch of imagination be referred to the Cambrian. If Prof. Blake refers to the Uriconian system, surely the most recent work tends to throw it further back from the Cambrian. But perhaps he will favour your readers with a few words of explanation.

Ch. Callawar.

Sandore, Weldington, Jan. $16 t h, 1890$.

\section{GROUND MORAINES.}

Srr,-I have just read in Professor James Geikie's Address to Section C, British Association, "Swiss geologists are agreed that the ground-moraines which clothe the bottoms of the great Alpine valleys, and extend outwards sometimes for many miles upon the low ground beyond, are of true glacial origin. Now these groundmoraines are closely similar to the Boulder-clays of this country [Britain] and Northern Europe."

We have in New Zealand, also, extensive deposits of ancient glaciers ; but $I$ have never seen in New Zealand any thing corresponding to the Boulder-clays and stratified tills of Britain; and if this is correct, it would follow that Boulder-clays cannot be the groundmoraines of glaciers.

The subject is an important one, and I would suggest that the British Association should send some one to New Zealand who is an expert in Boulder-clays, to settle the question. Two months in Otago, Canterbury, and Westland, between Norember and April, and three months for the two voyages, would be sufficient time, and the cost would not be more than $£ 200$ or $£ 250$.

I do not know any more promising geological work at the present day than a comparison of the glacial deposits of New Zealand with 